\author{
V.M. Gun'ko, V.V. Turov, T.V. Krupska
}

\title{
INTERFACIAL BEHAVIOR OF METHANE AND ORGANIC SOLVENTS WITH LOW FREEZING POINTS UPON INTERACTION WITH HYDROPHILIC AND HYDROPHOBIC NANOSILICAS
}

\author{
Chuiko Institute of Surface Chemistry of National Academy of Sciences of Ukraine \\ 17 General Naumov Str., Kyiv, 03164,Ukraine, E-mail: vlad_gunko@ukr.net
}

\begin{abstract}
Phase state features of adsorbed substance vs. temperature are often unknown or poorly defined due to strong effects of confined space in pores onto bound compounds. The adsorption theory considers that on a surface or in pores of adsorbents, adsorbate fluid forms structures with the density intermediate between ones of a gas and a liquid. The aim of the work was to study possibility for adsorbed substances to transform into solid state at temperature higher than freezing point. Solvent (acetone and ethanol) adsorption onto hydro-compacted nanosilica A-300 and its blend with hydrophobic AM1 (dimethyldichlorosilane hydrophobized A-300), methane adsorption onto hydrated $(\mathrm{h}=0.1 \mathrm{~g} / \mathrm{g}$ ) silicas, and water behavior vs. temperature were analyzed using ${ }^{1} H$ NMR spectroscopy, cryoporometry, and quantum chemistry. A fraction of organics bound to silicas is immobile at temperatures higher than its freezing point since it does not contribute to ${ }^{1} H$ NMR spectra of static samples. Methane signal increases with temperature because of enhanced molecular mobility and structure changes in mobile water clusters bound in voids between silica nanoparticles in their aggregates. Stronger compaction of A-300 than that of stirred A-300/AM1 (due to a negative effect of AM1 nanoparticles preventing formation of tight contacts between A-300 nanoparticles) leads to a decrease in adsorption of methane onto dense A-300 alone. Stronger stirring of the A-300/AM1 blend (at $h=0.1 \mathrm{~g} / \mathrm{g}$ ) leads to enhanced adsorption of methane. This effect is due to enhanced mobility of the methane molecules with $T$, because at low temperatures these molecules are practically immobile in voids between nanoparticles and frozen or poorly mobile water clusters, which partially fill narrow pores (voids) in NPNP aggregates and agglomerates.
\end{abstract}

Keywords: fumed silica, hydrophobized nanosilica, bound water organization, methane adsorption, organic solvent adsorption, low-temperature ${ }^{I} H$ NMR spectroscopy

\section{INTRODUCTION}

Adsorption features of gases, vapors or liquids are defined by a ratio of changes in the Gibbs free energies $(\Delta G)$ of an adsorbate at a surface and far from it (i.e. in bulk liquid or vapor/gas phase) [1-5]. A more negative value of $\Delta G$ for an adsorbate in the adsorption layer corresponds to stronger adsorption; i.e., interaction energy between adsorbed molecules and surface sites is greater than that between neighboring molecules of the adsorbate. However, phase state features of adsorbed substance vs. temperature are often unknown or poorly defined due to strong effects of confined space in pores onto bound compounds [6-15]. The adsorption theory [1-5] considers that on a surface or in pores of adsorbents, adsorbate fluid forms structures with the density intermediate between ones of a gas and a liquid. For nonpolar or weakly polar adsorbates, the adsorption starts on most active sites, then an adsorbate monolayer is formed, and polymolecular layer formation leads to micropore (pore radius $R<1 \mathrm{~nm}$, i.e. nanopores) and mesopore $(1 \mathrm{~nm}<R<25 \mathrm{~nm})$ volume filling and partial filling of macropores $(R>25 \mathrm{~nm}) \quad[1,2]$. However, for some substances (such as water), the adsorption to a hydrophilic surface leads to the cluster formation even at coverages greater than monolayer [14-18]. This is due to, at least, two reasons. First, each water molecule in any cluster tends to form several (2-4) hydrogen bonds with neighboring molecules that is easier than the formation of such bonds with surface sites only $[15,19]$. Second, the energy of molecular interactions in a surface cluster and of the cluster with the surface could be greater (due to the first reason) than that for water bound to the surface with keeping continuous adsorption monolayer $[15,19,20]$.

The adsorption leading to reduction of the Gibbs free energy causes freezing/melting point 
depression [15, 20-23]. The narrower the pore, the lower the freezing temperature of adsorbate in this pore that is described by the GibbsThomson relation [15, 21-23]. Despite lowering freezing point of adsorbates located in pores, their molecular mobility decreases due to confined space effects. This is well seen in broadening of ${ }^{1} \mathrm{H}$ NMR spectra of bound adsorbates [15]. Additionally, location of adsorbates in pores leads to their low mobility despite temperature higher than the melting point of the bulk liquid. Time of transverse relaxation $\left(T_{2}\right)$ registered in the NMR spectra decreases (NMR signal width grows) if substance freezes. Therefore, if a bandwidth of a NMR spectrometer is narrower than a signal width of immobile compounds, this signal is not observed in the ${ }^{1} \mathrm{H}$ NMR spectra of static samples. This allows one to study the temperature and interfacial behaviors of adsorbates (e.g. having the hydrogen atoms) at a surface of solids having the surface hydroxyls because the surface hydroxyls are characterized by the values of $T_{2}$ smaller by $3-5$ orders of magnitude than that of mobile small molecules in the adsorption phase $[15-18,20]$.

The interfacial and temperature behaviors of adsorbates depend on many factors [1-15, 24-38]. First, structure, molecular weight and size, polarity, a freezing/melting point and a character of interactions with neighboring molecules and a solid surface play an important role. Second, the textural characteristics and structure of an adsorbent surface affect the behavior of adsorbates $v s$. temperature. There is an important factor related to the hydrophilic/hydrophobic properties of adsorbents and adsorbates, especially in the case of nano-structured particles and/or mosaic surfaces. Fumed oxides (such as nanosilica unmodified or modified, e.g. hydrophobized) are the most known nano-structured adsorbents $[15,39-45]$. Fumed silica is composed of nonporous nanoparticles (NPNP), which form aggregates $(<1 \mu \mathrm{m})$ and agglomerates of aggregates $(>1 \mu \mathrm{m})$ characterized by the textural porosity with the parameters, especially the pore volume, dependent on any external action [15-17, 24, 39, 42]. Hydrophobization of nanosilica can be carried out by replacing surface hydroxyls by, e.g., trimethylsilyl groups (with no lateral cross-linking of the functionalities), dimethylsilyl groups (with lateral cross-linking of the functionalities), or other hydrophobic functionalities. Typically, the greater the amount of surface functionalities and the larger their length, the stronger the diminution of the textural characteristics of modified materials $[15,25]$. Despite numerous publications on fumed oxides, interfacial phenomena at a surface of blends with unmodified and hydrophobized nanosilicas were poorly studied; however, similar systems can be of interest from practical point of view. Therefore, the aim of this work was to study the interfacial phenomena and mentioned above effects with polar (water, ethanol, and acetone) and nonpolar (methane) adsorbates at a surface of a blend with hydrophilic (A-300) and hydrophobic (AM1) nanosilicas in comparison with that for A-300 alone. In this study, compacted nanosilicas were used to enhance their adsorption capability with no loss of the specific surface area. Adsorbates with very low freezing temperature, $T_{\mathrm{f}}$ (e.g., methane, ethanol, and acetone), as well as water characterizing by unique properties, could be selected to analyze features of the adsorption phase $v s$. temperature at $T>T_{\mathrm{f}}$ of methane, ethanol, and acetone, but at $T<T_{\mathrm{f}}$ of water under confined space effects. To analyze the effects of the surface nature of silicas on the adsorption phase vs. temperature, hydrophilic and hydrophobic adsorbents were used in this study.

\section{MATERIALS}

Hydrophilic nanosilica A-300
$\left(S_{\mathrm{BET}} \approx 290 \mathrm{~m}^{2} / \mathrm{g}, \quad\right.$ initial bulk density
$\left.\rho_{\mathrm{b}} \approx 0.05 \mathrm{~g} / \mathrm{cm}^{3}\right)$ was used as the initial material.
It was wetted (by water at content $h=0.5$ and
$3.0 \mathrm{~g} / \mathrm{g})$ and dried (at $433 \mathrm{~K}$ for $8 \mathrm{~h}) ;$ therefore,
the bulk density increased to 0.1 and $0.25 \mathrm{~g} / \mathrm{cm}^{3}$,
respectively. Hydrophobic AM1 (Pilot plant of
Chuiko Institute of Surface Chemistry, Kalush,
Ukraine) was prepared using A-300. A-300 was
modified by dimethyldichlorosilane (DMS)
cross-linkable due to formation of two OH
groups per hydrolyzed DMS molecule. A
mixture with treated A-300 (water-wetted-dried,
$\rho_{\mathrm{b}} \approx 0.25 \mathrm{~g} / \mathrm{cm}^{3}$, labeled here as dense A-300)
and AM1 (hexane-wetted-dried) (1:5) with
added (to A-300) water (at $h=0.1 \mathrm{~g}$ per gram of
both dry silicas) was weakly (with no strong
mechanical loading) or strongly stirred. Note that
water was added to dense A-300 $(h=0.6 \mathrm{~g} / \mathrm{g})$,


which was then mixed with AM1 (1:5) that gave $h=0.1 \mathrm{~g} / \mathrm{g}$. These samples were used to study the adsorption of methane. Upon the methane adsorption, $5 \mathrm{~mm}$ NMR ampoule with a sample (100-200 mg) was connected to a rubber vessel with methane (freezing point $T_{\mathrm{f}}=90.7 \mathrm{~K}$ ) at $1.1 \mathrm{~atm}$. The value of $h=0.1 \mathrm{~g} / \mathrm{g}$ corresponding to maximal adsorption of methane onto nanosilica $[15,46]$ was selected for this study. Additionally, stirred dried samples were wetted by acetone $\left(T_{\mathrm{f}}=178.5 \mathrm{~K}\right)$ or ethanol $\left(T_{\mathrm{f}}=159.0 \mathrm{~K}\right)$ using $1 \mathrm{~g}$ of a liquid per gram of dry silica, and then the system was carefully mixed, but with no strong mechanical loading.

Scanning electron microscopy, SEM (Nova NanoSEM 450, FEI) was used to analyze the morphology of water-wetted-dried nanosilica A-300 studied under low vacuum condition and using a carbon plate to deposit the powdered sample.

\section{${ }^{1} \mathrm{H}$ NMR SPECTROSCOPY}

${ }^{1} \mathrm{H}$ NMR spectra of static samples (placed into 4 and $5 \mathrm{~mm}$ NMR ampoules) weakly hydrated at $h=0.1 \mathrm{~g} \mathrm{H}_{2} \mathrm{O}$ per gram of dry silica with subsequent adsorption of methane, or wetted by acetone or ethanol $(1 \mathrm{~g} / \mathrm{g})$ were recorded using a Varian 400 Mercury spectrometer (magnetic field $9.4 \mathrm{~T}$, bandwidth $20 \mathrm{kHz}$ ) utilizing eight $60^{\circ}$ pulses of $1 \mu \mathrm{s}$ duration. Relative mean errors were less than $\pm 10 \%$ for ${ }^{1} \mathrm{H}$ NMR signal intensity for overlapped signals, and $\pm 5 \%$ for single signals. Temperature control was accurate and precise to within $\pm 1 \mathrm{~K}$. The accuracy of integral intensities was improved by compensating for phase distortion and zero-line nonlinearity with the same intensity scale at different temperatures. To prevent supercooling of water in samples, the beginning of spectra recording was started at 196-210 K. Samples precooled to this temperature for $10 \mathrm{~min}$ were then heated to $282-285 \mathrm{~K}$ at a rate of $5 \mathrm{~K} / \mathrm{min}$ with steps $\Delta T=10 \mathrm{~K}$ or $5 \mathrm{~K}$ at a heating rate of $5 \mathrm{~K} / \mathrm{min}$ for $2 \mathrm{~min}$. They were maintained at a fixed temperature for $5 \mathrm{~min}$ for data acquisition at each temperature for $1 \mathrm{~min}$ [15].

Upon methane adsorption, $5 \mathrm{~mm}$ NMR ampoule with a sample (100-200 mg) containing a certain amount of water $(h=0.1 \mathrm{~g} / \mathrm{g})$ was connected to a rubber vessel with methane at pressure of $1.1 \mathrm{~atm}$. Then this ampoule was placed into a NMR detecting device that allows the adsorption-desorption of methane with temperature changes [15]. Thus, the NMR measurements were carried out under isobaric conditions.

The applications of the low-temperature ${ }^{1} \mathrm{H}$ NMR spectroscopy and NMR cryoporometry, based on the freezing point depression of liquids located in pores dependent on the pore size, to numerous objects were described in detail elsewhere [15, 20-23]. Note that high-molecular weight compounds and solids do not contribute to the ${ }^{1} \mathrm{H}$ NMR spectra recorded here due to a large difference in the transverse relaxation times of liquid or fluid (mobile) small compounds (such as water, methane, acetone, ethanol, etc.) and immobile components (such as solids, macromolecules, or immobile small molecules) and due to a narrow bandwidth $(20 \mathrm{kHz})$ of the spectrometer used [15, 47].

\section{INFRARED SPECTRA}

The IR spectra of powdered samples of initial A-300 and AM1 over the $4000-300 \mathrm{~cm}^{-1}$ range (at $4 \mathrm{~cm}^{-1}$ resolution) were recorded in transmission mode using a Specord M80 (Carl Zeiss, Jena) spectrometer using sample powders pressed at $99 \mathrm{MPa}$ to form thin tablets $(\sim 20 \mathrm{mg})$.

\section{QUANTUM CHEMICAL CALCULATIONS}

Quantum chemical calculations were carried out using a density functional theory (DFT) method with a hybrid functional $\omega B$ 97X-D $[48,49]$ (labelled as wB97XD in Gaussian 09) with the cc-pVDZ or aug-cc-pVTZ basis sets using the Gaussian 09 program suit [48]. The solvation effects were analyzed using the solvation method SMD [50] implemented in Gaussian 09. The gauge-independent atomic orbital (GIAO) method [48] was used to calculate the NMR spectra of certain clusters of studied compounds (up to 330 atoms). Larger structures (up to 15000 atoms) were calculated using semiempirical PM7 method (MOPAC 2016) $[51,52]$.

\section{RESULTS AND DISCUSSION}

SEM images of dense A-300 (Fig. 1) and weakly compacted A-300 suggest that the morphology of the treated silicas is practically similar to that characteristic for initial fumed silicas [15] despite certain compaction of secondary particles. This compaction of the A-300 powder $\left(\rho_{b}\right.$ increases 
from 0.05 to $0.25 \mathrm{~g} / \mathrm{cm}^{3}$, Fig. 1) during wettingdrying occurs due to changes in the organization of the secondary particles (i.e. aggregates of NPNP and agglomerates of aggregates). However, the morphology of NPNP per se (size, shape and surface structure) does not practically change because wetting-drying and hand stirring of samples in a porcelain mortar provides relatively low mechanical loading (smaller than $100 \mathrm{~kg} / \mathrm{cm}^{2}$ ).

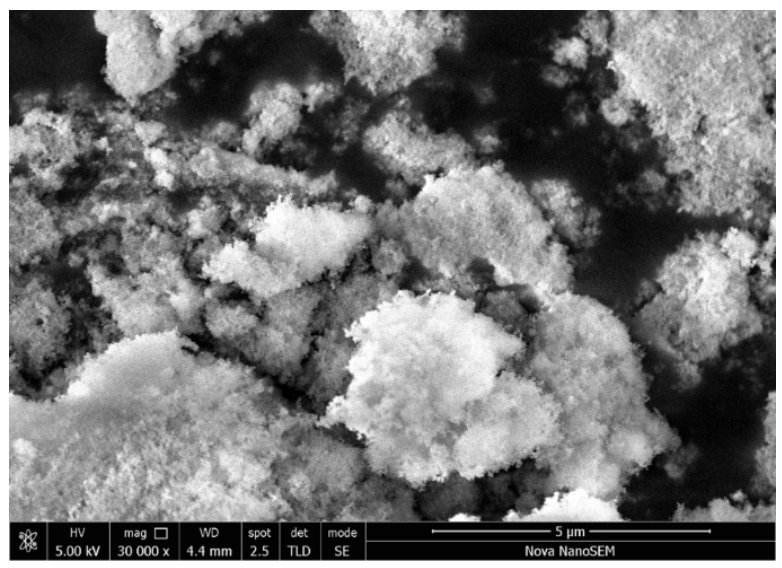

$a$

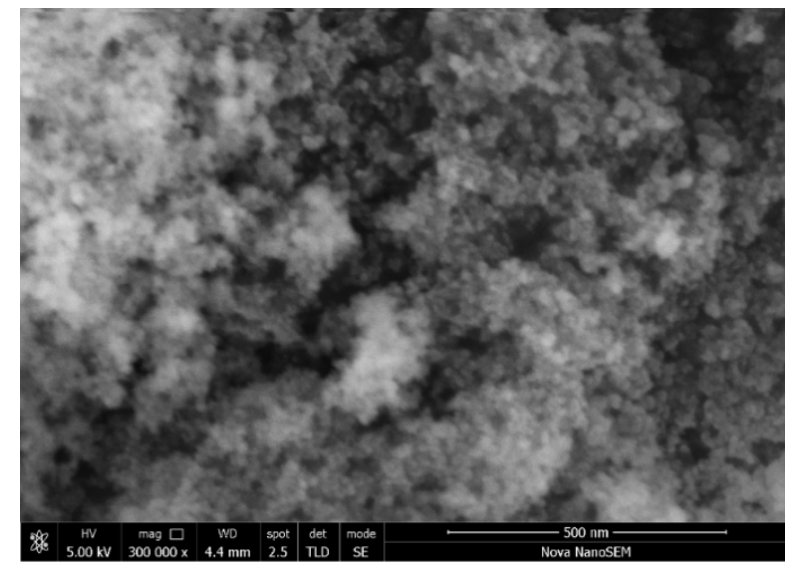

b

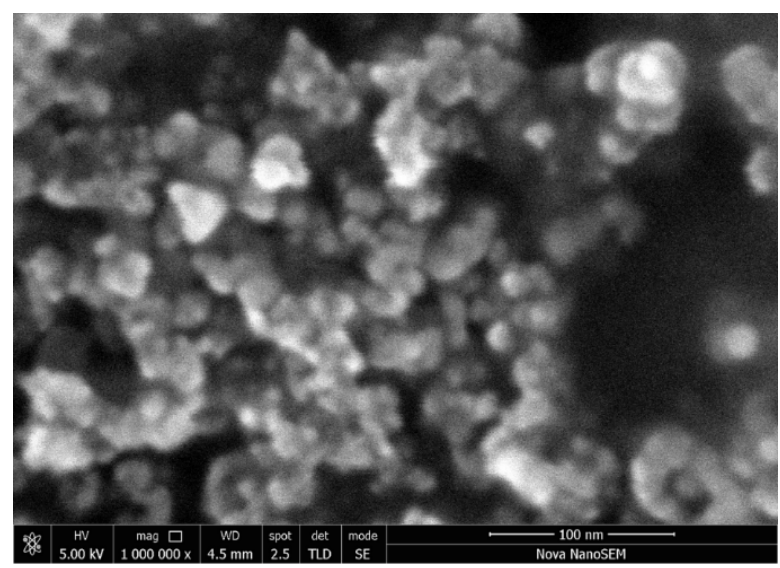

Fig. 1. SEM images of dense A-300 $\left(\rho_{\mathrm{b}} \approx 0.25 \mathrm{~g} / \mathrm{cm}^{3}\right)$ (scale bar $(a) 5 \mu \mathrm{m},(b) 500 \mathrm{~nm}$, and (c) $100 \mathrm{~nm}$ )

Note that treatment of nanosilicas at high pressure (up to $1050 \mathrm{~atm}$ ) does not practically change the specific surface area, but the pore volume changes due to the compaction of the secondary particles $[53,54]$. Stirring of a blend with dense A-300 and AM1 (1:5) leads to the powders with the value of $\rho_{\mathrm{b}}$ smaller $\left(\sim 0.13 \mathrm{~g} / \mathrm{cm}^{3}\right)$ than that of dense A-300 because surface hydrophobic functionalities of NPNP of AM1 prevent the formation of tight contacts between neighboring particles. Hexane-wettingdrying of AM1 provides $\rho_{\mathrm{b}} \approx 0.1 \mathrm{~g} / \mathrm{cm}^{3}$. Therefore, the average value of $\rho_{b}$ for the dense A-300/AM1 (1:5) mixture is about $0.13 \mathrm{~g} / \mathrm{cm}^{3}$.

The pore size distributions (PSD) of nanosilicas (determined from nitrogen adsorption-desorption isotherms using a model of voids between NPNP in the secondary particles [15, 55]) (Fig. 2) demonstrate a larger contribution of broad pores in the range of $R=10-100 \mathrm{~nm}$ than that of narrow pores at $R<10 \mathrm{~nm}$. This is due to the nature of fumed oxides composed of NPNP forming very loose powders. The empty volume, which is large as $V_{\mathrm{em}}=1 / \rho_{\mathrm{b}}-1 / \rho_{0}=10-25 \mathrm{~cm}^{3} / \mathrm{g} \quad$ (where $\rho_{\mathrm{b}}=0.04-0.13 \mathrm{~g} / \mathrm{cm}^{3}$ for various nanosilicas, and $\rho_{0}=2.2 \mathrm{~g} / \mathrm{cm}^{3}$ is the true density of NPNP of nanosilica), can be about $95 \%$ for the initial nanooxide powders. For example, $\rho_{\mathrm{b}}=0.045,0.1$ and $0.25 \mathrm{~g} / \mathrm{cm}^{3}$ for initial and compacted nanosilicas A-300 that correspond to $V_{\mathrm{em}}=21.8$, 9.5 , and $3.5 \mathrm{~cm}^{3} / \mathrm{g}$. However, the $V_{\mathrm{p}}$ values (from nitrogen adsorption at relative pressure 
$\left.p / p_{0} \approx 0.99\right)$ are much lower $\left(0.524 \mathrm{~cm}^{3} / \mathrm{g}\right.$ at $\rho_{\mathrm{b}}=0.045 \mathrm{~g} / \mathrm{cm}^{3}$ and $1.4 \mathrm{~cm}^{3} / \mathrm{g}$ at $\left.\rho_{\mathrm{b}}=0.25 \mathrm{~g} / \mathrm{cm}^{3}\right)[15,56]$. The $V_{\mathrm{p}}$ value is much lower for the initial A-300 than that for dense one because nitrogen cannot effectively fill broad macropores and this filling increases due to the compaction of the powder $[1,2]$. Therefore, water amounts adsorbed onto initial A-300 from air is low (1-4 wt. \%) [15]. This was a reason why dense A-300 (possessing greater adsorption capability) was used in the study. Hydrophobic AM1 is characterized by lower PSD intensity than hydrophilic A-300 because grafting of functionalities and their lateral crosslinking lead to a decrease in the pore volume and specific surface area (since size of modified NPNP increases).

Despite strong hydrophobization of a NPNP surface by DMS in AM1, residual free silanols are observed in the infrared (IR) spectra (Fig. 3) because not all the $\mathrm{OH}$ groups of hydrolyzed DMS can participate in the lateral cross-linking reaction due to structural factors [16-18, 24]. However, the amounts of free silanols and water adsorbed from air are much smaller for AM1 than that for unmodified A-300 (Fig. 3).

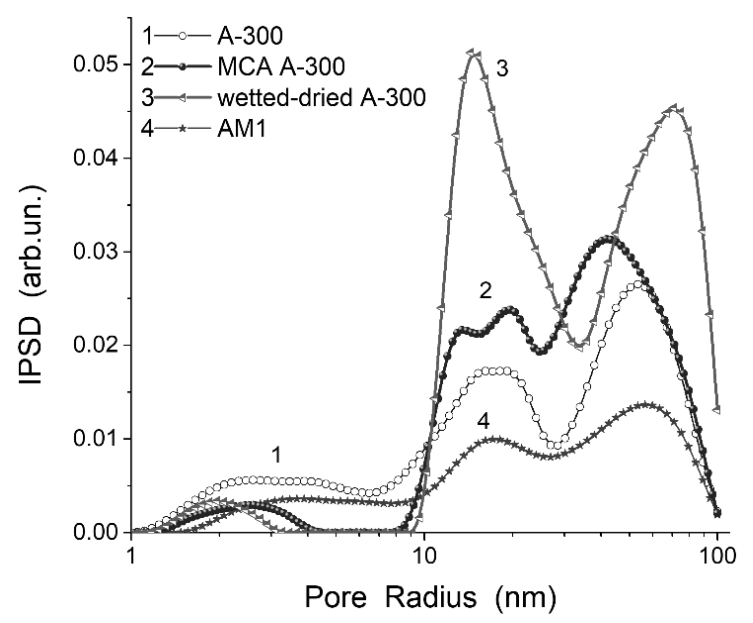

Fig. 2. Incremental pore size distributions of A-300 initial and differently treated (mechanochemical activation (MCA) for $2 \mathrm{~h}$ in a ball-mill, and wetted and dried) and chemically modified by dimethyldichlorosilane (AM1) calculated using DFT method with a model of pores as voids between nonporous spherical nanoparticles)

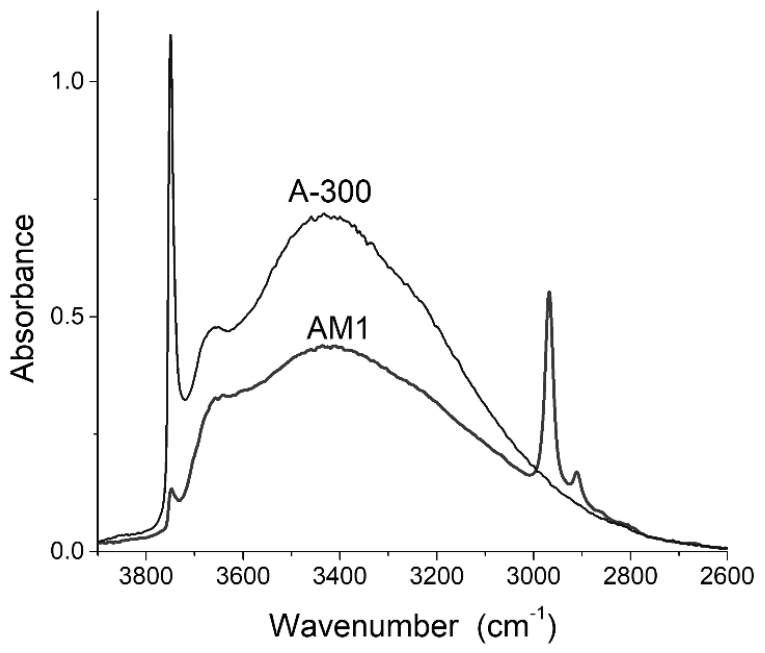

Fig. 3. IR spectra of initial nanosilica A-300 and hydrophobic AM1

The textural characteristics of the powders, the surface structure of unmodified and hydrophobized A-300, and the organization of
NPNP in the secondary structures can strongly affect the temperature and interfacial behaviors of polar (water, ethanol, and acetone) and 
nonpolar (methane) adsorbates [15]. These effects were studied using low-temperature ${ }^{1} \mathrm{H}$ NMR spectroscopy (with a narrow bandwidth of $20 \mathrm{kHz}$ ) applied to static samples (to separate mobile and immobile phases of adsorbates in the samples).

In the ${ }^{1} \mathrm{H}$ NMR spectra of the systems containing acetone (Fig. $4 a$ ), a broad signal is observed at the chemical shift of proton resonance $\delta_{\mathrm{H}}=2.5 \mathrm{ppm}$ corresponding to the methyl groups of acetone. This signal is broad due to low mobility of molecules located in voids between NPNP in the secondary particles. For adsorbed ethanol (Fig. $4 \mathrm{~b}$ ), there are three broad signals attributed to methyl, methylene, and hydroxyl groups at $\delta_{\mathrm{H}}=2,4$, and $5.5 \mathrm{ppm}$, respectively. The signal corresponding to the hydroxyl groups of ethanol is also contributed by water, which is present in the alcohol as an admixture (ethanol with concentration of 96 wt. $\%+4$ wt. $\%$ of water was used). As appears from Fig. 4, with increasing temperature, signal of the methyl and methylene groups of ethanol increases more than twice at $T$ from $196-210 \mathrm{~K}$ to $285 \mathrm{~K}$. Thus, despite $T>T_{\mathrm{f}}$ of organic solvents, a fraction of them is not observed in ${ }^{1} \mathrm{H}$ NMR spectra $(20 \mathrm{kHz}$ bandwidth) due to strong immobilization of molecules bound to a surface of compacted silica in narrow voids between NPNP in their aggregates and agglomerates of aggregates. Relative intensity of signals of hydroxyls at low temperatures becomes greater because a fraction of bound water can be unfrozen in the temperature range used.

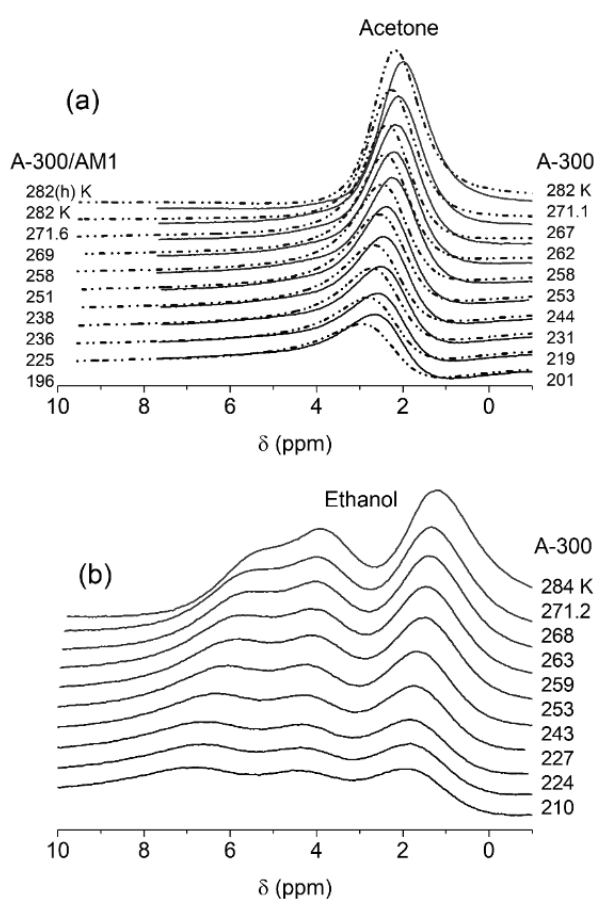

Fig. 4. $\quad{ }^{1} \mathrm{H}$ NMR spectra recorded at different temperatures of acetone $(a)$ and ethanol $(b)$ interacting with dense A-300 ( $a$, solid lines, and $b$ ) and a blend of dense A-300 with AM1 (1:5 w/w) ( $a$, dashed lines)

Practically total amount of liquids is mobile at $T=282 \mathrm{~K}$ (Fig. 5). To check this, a sample with adsorbed acetone heated to $282 \mathrm{~K}$ was additionally heated to $320 \mathrm{~K}$, and then cooled to $282 \mathrm{~K}$ (spectrum 282(h) K (Fig. 4a) and the corresponding point shown in Fig. 5). The difference in signal intensity for samples heated at $282 \mathrm{~K}$ and $282 \rightarrow 320 \rightarrow 282 \mathrm{~K}$ is about $5 \%$. Thus, according to Fig. 5, a significant fraction of liquids located in voids between NPNP in the secondary structures is practically immobile at $T>T_{\mathrm{f}}$. The volume of this fraction at $200 \mathrm{~K}$ is smaller than the total pore volume $\left(V_{\mathrm{p}}=1.42 \mathrm{~cm}^{3} / \mathrm{g}\right)$ or the mesopore volume $\left(V_{\text {meso }}=0.59 \mathrm{~cm}^{3} / \mathrm{g}\right)$ of treated A-300 at $\rho_{\mathrm{b}} \approx 0.25 \mathrm{~g} / \mathrm{cm}^{3}$. These results can be explained by a large difference in the interaction energy in complexes of the molecules with silanols and complexes of molecules per se calculated taking into account the solvation effects (Fig. 6). 


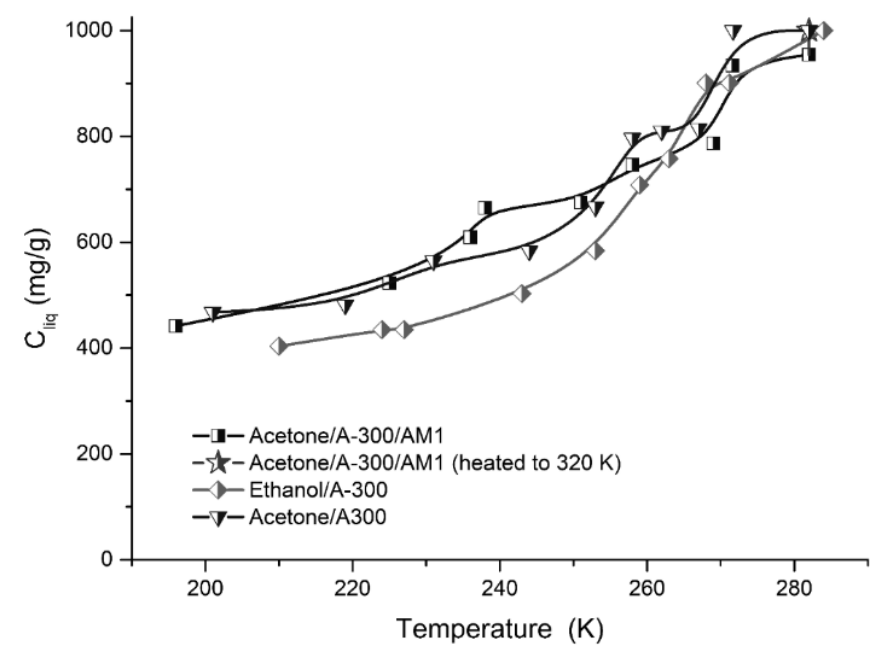

Fig. 5. The temperature dependences of concentration of mobile acetone or ethanol $(1 \mathrm{~g} / \mathrm{g})$ interacting with dense A-300 or A-300/AM1 (1:5 w/w) calculated using signal intensity of methyl groups (errors are smaller than $\pm 5 \%$ )
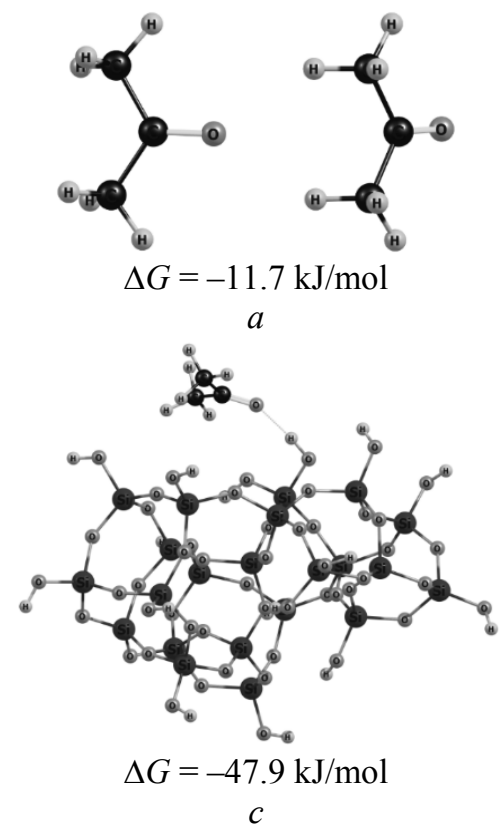
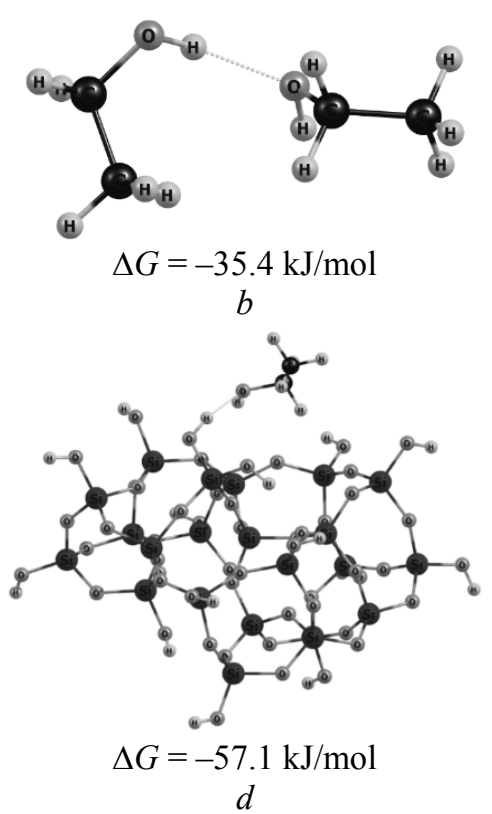

Fig. 6. Molecular structures of dimers of $(a)$ acetone and $(b)$ ethanol and adsorption complexes of $(c)$ acetone and $(d)$ ethanol at a surface of silica cluster composed with $22 \mathrm{SiO}_{4 / 2}$ units $(\mathrm{SMD} / \omega \mathrm{B} 97 \mathrm{X}-\mathrm{D} / \mathrm{cc}-\mathrm{pVDZ}$ method). The values of the Gibbs free energy of complex formation taking into account the solvation effects $(\Delta G)$ are shown

For bound acetone, the energy is greater (by modulus) by four times than that for the molecular complex with two molecules $(-47.9$ and $-11.7 \mathrm{~kJ} / \mathrm{mol}$, respectively). For ethanol, this difference is smaller $(-57.1$ and $-35.4 \mathrm{~kJ} / \mathrm{mol})$ because the ethanol molecules can form strong hydrogen bonds with both silanols and other alcohol molecules. Note that the corresponding values for propanol (-57.0 and $-39.9 \mathrm{~kJ} / \mathrm{mol})$ are close to that for ethanol. Thus, the hydrogen bonds play the main role in the difference between adsorbed acetone and alcohols. Stronger bonding of ethanol to A-300 leads to an enhanced fraction of immobile molecules in comparison with acetone (Fig. 5). The behavior of acetone bound to A-300 is similar to that for A-300/AM1 (1:5) because acetone (due to polar $\mathrm{C}=\mathrm{O}$ and nonpolar $\mathrm{CH}_{3}$ groups) can well wet a surface of both hydrophilic and hydrophobic silicas. 
Besides liquid organic solvents, adsorption of methane (at pressure 1.1 bar) onto nanosilicas was studied but with pre-adsorbed water $(h=0.1 \mathrm{~g} / \mathrm{g})$ (Fig. 7). An adsorbent blend of hydrophilic (dense A-300) and hydrophobic (AM1) (at $1: 5 \mathrm{w} / \mathrm{w}$ ) was used as initial one (mixed without strong mechanical loading for $5 \mathrm{~min}$ ) and strongly stirred (after addition of water to A-300) to form uniform blend to compare with dense A-300 alone (Fig. 7). Since the amount of water in samples is precisely known, the ratio of integral intensity of ${ }^{1} \mathrm{H}$ NMR signals of water and methane at each temperature allows us to estimate their quantity being in a mobile state registered in the ${ }^{1} \mathrm{H}$ NMR spectra of high resolution.
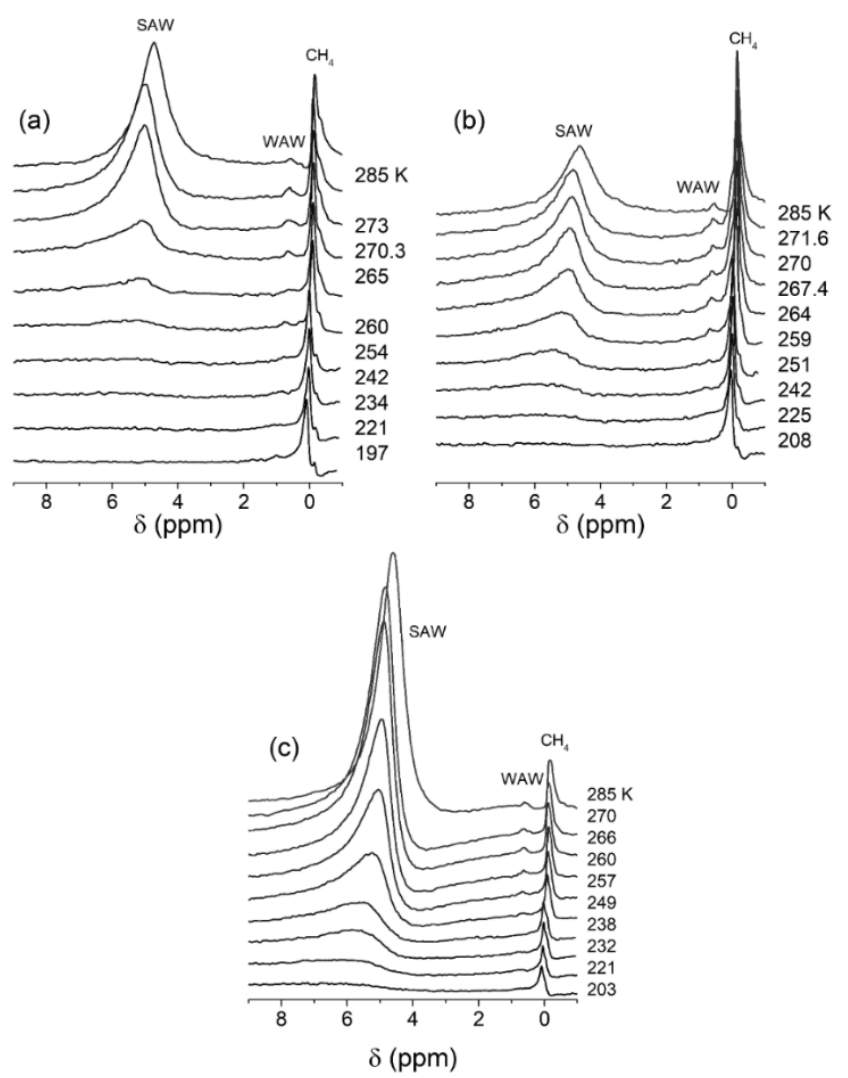

Fig. 7. ${ }^{1} \mathrm{H}$ NMR spectra recorded at different temperatures of water $(h=0.1 \mathrm{~g} / \mathrm{g})$ and methane adsorbed onto $(a)$ initial blend of treated A-300 and AM1; $(b)$ this blend after strong stirring of the mixture (mechanical loading $>100 \mathrm{~kg} / \mathrm{cm}^{2}$ ); and (c) dense A-300

Water is observed in the spectra (Fig. 7) as ${ }^{1} \mathrm{H}$ NMR signals at $\delta_{\mathrm{H}} \approx 4.5-5.5$ and $1 \mathrm{ppm}$ corresponding to strongly (SAW) and weakly (WAW) associated waters, respectively [15]. Signal intensity of SAW strongly decreases with decreasing temperature due to partial freezing of bound water at $T<T_{\mathrm{f}}$ of water. Highly mobile methane molecules are characterized by a relatively narrow signal at $\delta_{\mathrm{H}} \approx 0 \mathrm{ppm}$. Signal intensity of methane weakly changes with decreasing temperature because $T>>T_{\mathrm{f}}$ of methane. Spectral contribution of methane being in the gas phase is relatively low (this is also clear from comparison of the amounts of adsorbed methane for different samples, vide infra).
Minimal adsorption of methane $(2.5 \mathrm{mg} / \mathrm{g})$ is observed for hydrophilic dense A-300 at $h=0.1 \mathrm{~g} / \mathrm{g}$ (Table 1, Fig. $8 a$ ). It increases up to $10 \mathrm{mg} / \mathrm{g}$ for the composite weakly treated and becomes maximum $(25 \mathrm{mg} / \mathrm{g})$ for the strongly stirred composite. These differences can be explained by several factors. First, silicas are characterized by different PSD (Fig. 2). Second, pre-adsorbed water fills narrow voids, and if the volume of these voids decreases (e.g. in dense A-300) that secondary porosity caused by bound water clusters (Figs. $8 c, d$ ) can be less appropriate for the adsorption of methane. Upon strongly stirring of A-300/AM1, dense structures of A-300 can be partially destroyed. A major 
fraction of water is remained in state bound to A-300 since AM1 can adsorb small amounts of water (Fig. 3). Therefore, conditions for the
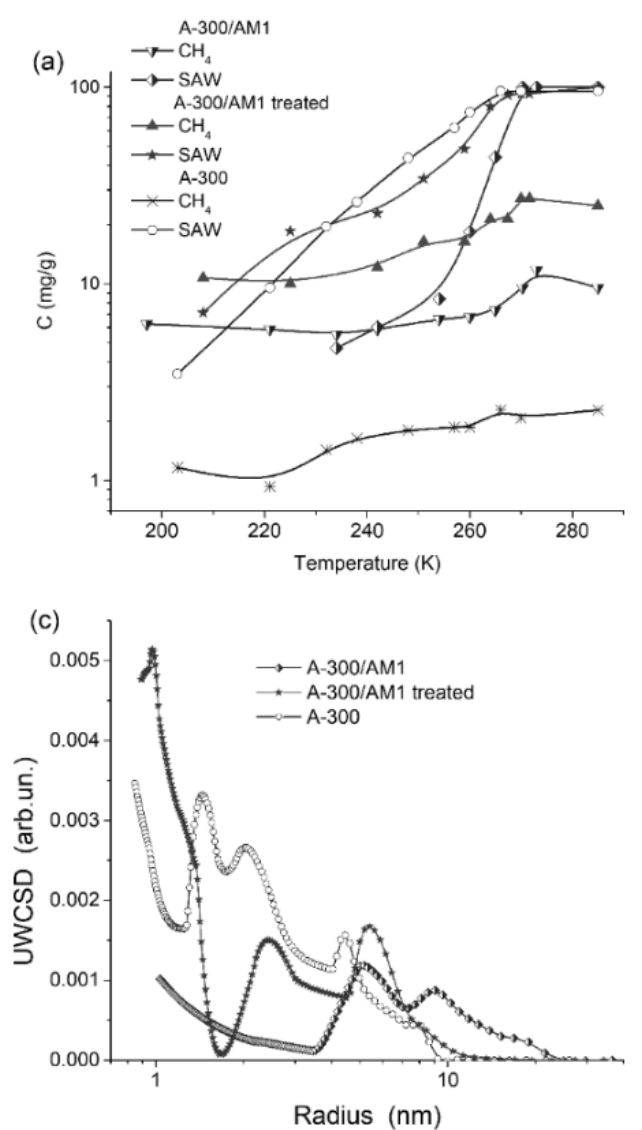

adsorption of methane become more appropriate than that for dense A-300 alone that leads to maximal adsorption of methane.
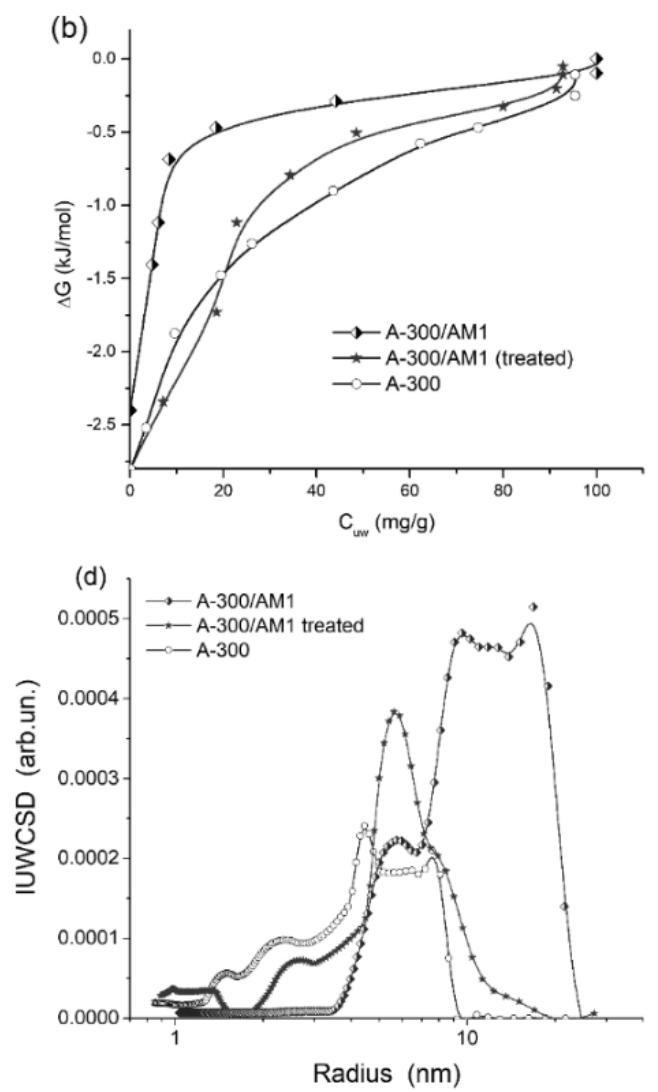

Fig. 8. (a) Temperature dependences of concentration of mobile phases of water and methane (errors are smaller than $\pm 5 \%),(b)$ relationship between changes in the Gibbs free energy; and $(c, d)$ unfrozen water cluster size distributions (UWCSD) differential $(c)$ and incremental $(d)$ for initial and stirred blends of dense A-300/AM1 (1:5) and dense A-300 calculated using NMR cryoporometry

In the case of the weakly treated blend with A-300/AM1, the adsorption conditions for methane are worse than that for the strongly treated blend because of the difference in the particle organization. Since water was added to A-300, which was then mixed with AM1 (1:5) and then weakly treated, a fraction of hydrated A-300 can form certain shells around secondary particles with hydrophobic NPNP of AM1. However, the amount of water is relatively low ( $0.6 \mathrm{~g}$ per gram of A-300 or $0.1 \mathrm{~g}$ per gram of both silicas), as well as A-300 in the A-300/AM1 blend, to form core-shell secondary structures at a microscale level upon strong decomposition of large secondary particles of AM1. Therefore, the adsorption of methane onto the weakly treated blend is higher than that for the dense A-300 alone at the same $h=0.1 \mathrm{~g} / \mathrm{g}$. Upon strongly stirring, the core (AM1) - shell (A-300 + water) structures were destroyed that resulted in the increase in the adsorption of methane. A certain increase in signal intensity of methane (Figs. 7 and $8 a$ ) with increasing temperature can be due to increased mobility of bound molecules, which were practically immobile at low temperatures. This is similar to the effects for ethanol and acetone (Figs. 4 and 5). Thus, the adsorption of methane depends on the presence of hydrophobic AM1 and treatment type of the A-300/AM1 blend.

According to theoretical calculations of the ${ }^{1} \mathrm{H}$ NMR spectra of the systems containing acetone, ethanol, water, methane, hydrophilic and hydrophobic silica models (Figs. 9-14), adsorbed methane can affect the behavior of bound water, as well as water affects the adsorption of methane, or organic solvents affect 
the water state. The lines of water (dissolved in ethanol) in the spectra are well masked by the lines of the ethanol hydroxyls (Fig. 10) in contrast to water dissolved in acetone (Fig. 9). As a whole, the theoretical spectra (both DFT/GIAO and PM7/correlation functions for water, acetone, ethanol, and methane) are in agreement with the experimental data. An ice(Ih)-shaped cluster of water demonstrates larger values of $\delta_{\mathrm{H}}$ (Fig. 11, curve 3) than the clusters of amorphous water (curves 5 and 6 ). Solvation of the ice-shaped cluster in water (GIAO/SMD calculation for the geometry calculated with SMD taking into account the solvation effects) gives the spectrum (Fig. 11, curve 4) close to that of amorphous water. Note that the methods of the geometry optimization ( $a b$ initio, DFT, $\mathrm{SMD} / \mathrm{DFT}$ ), as well as the used basis sets, can affect the shape of the theoretical ${ }^{1} \mathrm{H}$ NMR

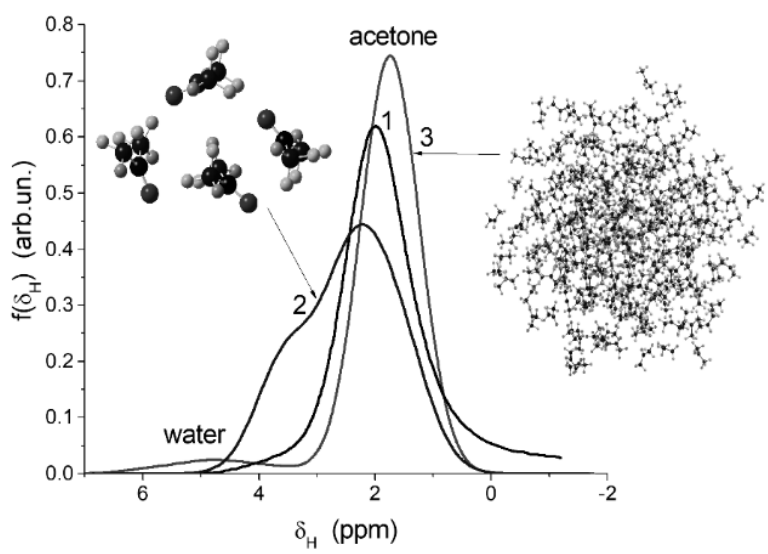

Fig. 9. Experimental ${ }^{1} \mathrm{H}$ NMR spectrum of acetone bound to dense A-300 (at $282 \mathrm{~K}$ ) (curve 1) and theoretical spectra of an acetone cluster with four molecules

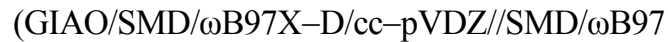

$\mathrm{X}-\mathrm{D} / \mathrm{cc}-\mathrm{pVDZ}$ ) (curve 2), and an acetone cluster with 216 molecules and $16 \mathrm{H}_{2} \mathrm{O}$ inside the cluster (PM7) (curve 3)

The spectrum of a water cluster in hydrophobic surroundings differs from that for the same cluster but in hydrophilic (water) one (Fig. 11, curves 1 and 2). Similar changes in the spectra are observed for methane molecules located in nanopores formed by a water cluster (Figs. 13 and 15) or upon water and methane coadsorption onto silica nanoparticles partially hydrophobized (Figs. 12 and 15). For latter, the chemical shifts of methane molecules are slightly spectra (Fig. 12). It is better to use the same method (DFT or SMD/DFT) to optimize the geometry and to calculate the ${ }^{1} \mathrm{H}$ NMR spectra of the optimized system (using the GIAO method). For example, enlarging basis set (to aug-cc-pVTZ from cc-pVDZ) upon the calculation of the ${ }^{1} \mathrm{H}$ NMR spectrum of $44 \mathrm{H}_{2} \mathrm{O}$

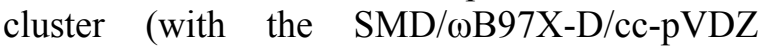

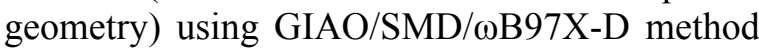
leads to a certain downfield shift of the spectrum (Fig. 12, curves 2 and 3) due to non-zero derivatives of the energy by atomic coordinates calculated with the basis set different from that used upon the geometry optimization. Therefore, in all other cases, the ${ }^{1} \mathrm{H}$ NMR spectra were calculated using the same method (DFT or $\mathrm{SMD} / \mathrm{DFT}$ ), which was used to geometry optimization with the same basis set.

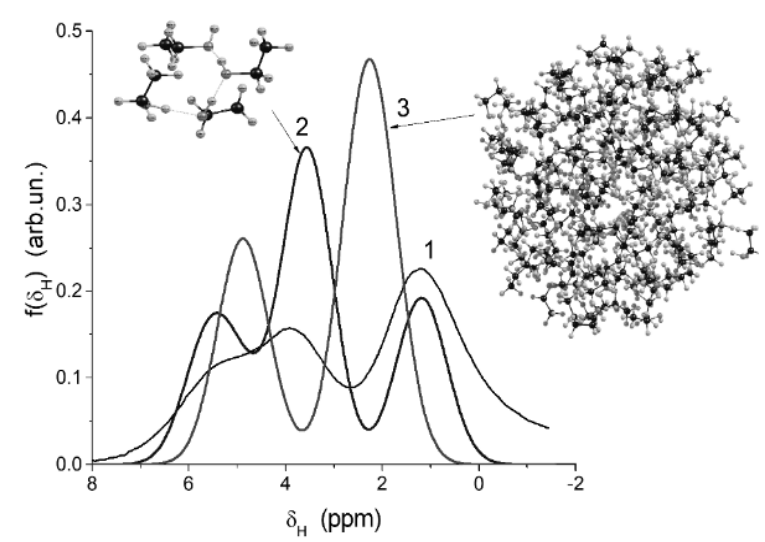

Fig. 10. Experimental ${ }^{1} \mathrm{H}$ NMR spectrum of ethanol bound to dense A-300 (at $282 \mathrm{~K}$ ) (curve 1) and theoretical spectra of an ethanol cluster with four molecules

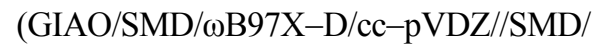
$\omega \mathrm{B} 97 \mathrm{X}-\mathrm{D} / \mathrm{cc}-\mathrm{pVDZ}$ ) (curve 2), and an ethanol cluster with 140 molecules and $16 \mathrm{H}_{2} \mathrm{O}$ inside the cluster (PM7) (curve 3)

greater than that for methane molecules interacting only with the water cluster (Fig. 15, curves 2 and 3). Thus, the effects observed in the NMR experiments with co-adsorption of water and methane, there is reciprocal action of both co-adsorbates; i.e., not only pre-adsorbed water affects the behavior of adsorbed methane, but also adsorbed methane can affect the behavior of bound water. 


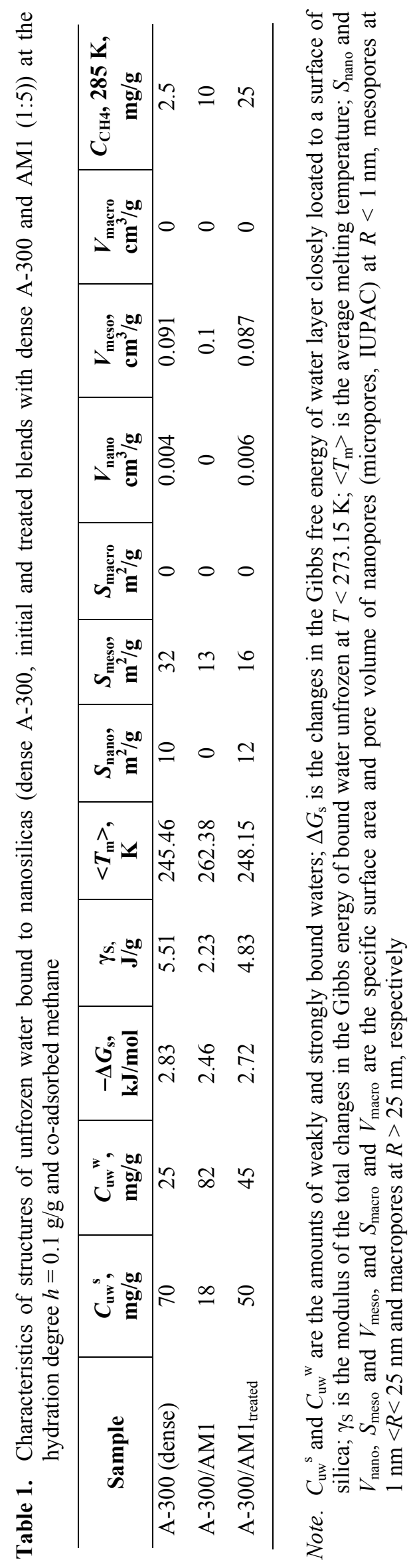




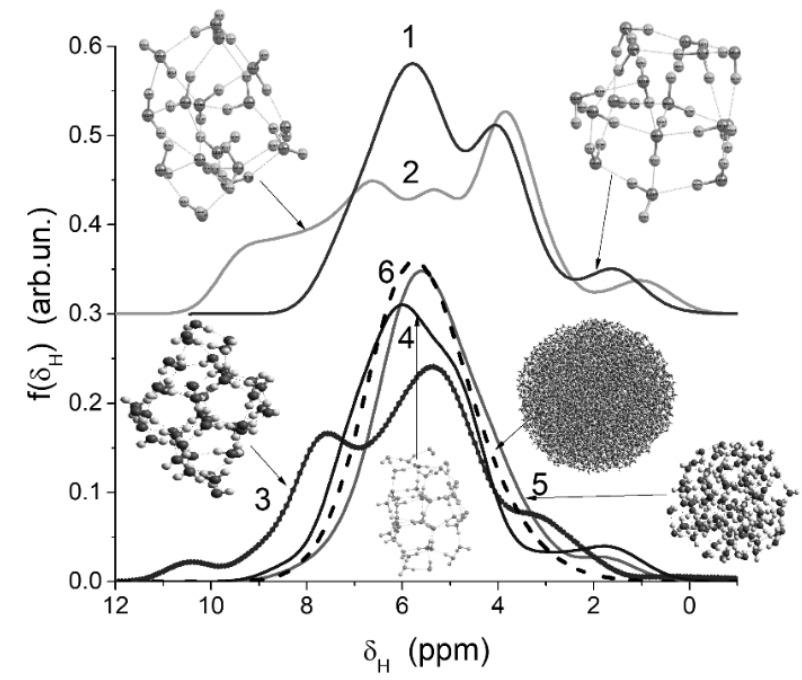

Fig. 11. Theoretical ${ }^{1} \mathrm{H}$ NMR spectra of water clusters (with $16 \mathrm{H}_{2} \mathrm{O}$ taking account solvation in water (curve 1 ) or hexane (2), $44 \mathrm{H}_{2} \mathrm{O}$ in vacuum (3) or water (4), $100 \mathrm{H}_{2} \mathrm{O}$ in water (5), and $5000 \mathrm{H}_{2} \mathrm{O}$ in vacuum (6)) calculated using the

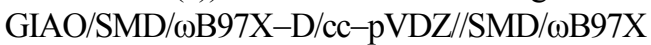
$-\mathrm{D} / \mathrm{cc}-\mathrm{pVDZ}$ (curves 1, 2, 4, and 5) or

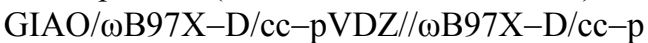
VDZ methods (3) and PM7 (6) (area under all curves was normalized to 1 and the second basis set (//) was used for the geometry optimization)

Adsorbed water can be differentiated according to the temperature ranges of its freezing $[15,20]$. If it is frozen at $265 \mathrm{~K}<T<273 \mathrm{~K}$ that it can be attributed to weakly bound water (WBW). If it is frozen at lower temperatures at $T<265 \mathrm{~K}$ that it is strongly bound water (SBW) [15]. The value of $\Delta G_{\mathrm{s}}$ (Table 1) defines the maximum decrease in the Gibbs free energy in the surface monolayer of bound water [15]. The maximum quantity of SBW (Table $1, C_{\mathrm{uw}}{ }^{\mathrm{s}}$ ) is observed for hydrophilic dense A-300. A little smaller value of $C_{\text {uw }}{ }^{\text {s }}$ is for the mechanoactivated blend of A-300/AM1. It is minimal for the weakly treated blend (without strong mechanical loading). The value of $\gamma_{\mathrm{S}}$, which defines the modulus of the total decrease in the Gibbs free energy of bound water, and the average melting temperature $<T_{\mathrm{m}}>$ change (Table 1) according to the values of $\Delta G_{\mathrm{s}}$ and $C_{\mathrm{uw}} \mathrm{s}$. This is due to much stronger effects for water located close to a surface of silica NPNP in voids than that for water located far from the surface and out of the voids.

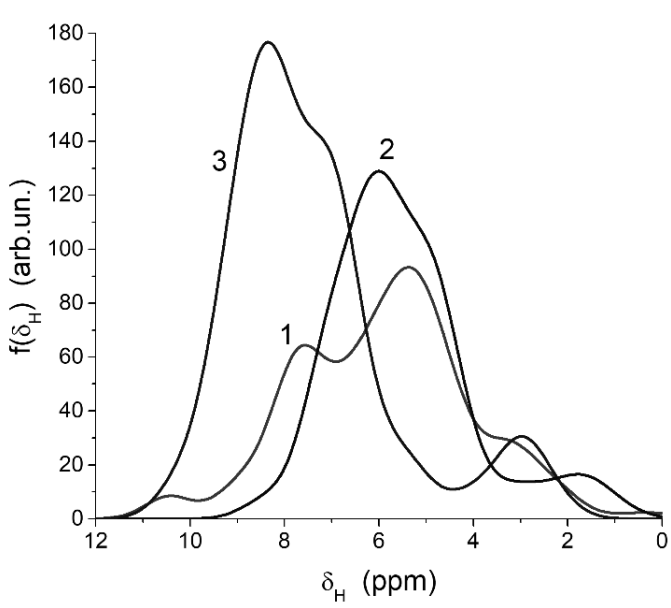

Fig. 12. Theoretical ${ }^{1} \mathrm{H} N \mathrm{NR}$ spectra of a water cluster with $44 \mathrm{H}_{2} \mathrm{O}$ in vacuum (curve 1 ) calculated using the GIAO method with the $\omega B 97 X-D / c c-p V D Z / / \omega B 97 X-D / c c-p V D Z$ basis set, and taking into account solvation in water with the $\mathrm{SMD} / \omega \mathrm{B} 97 \mathrm{X}-\mathrm{D}$ method using cc-pVDZ//SMD/ $/$ B97X-D/cc-pVDZ (curve 2)

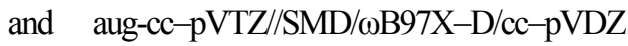
(curve 3) basis sets
Unfrozen water cluster size distributions (UWCSD calculated using the NMR cryoporometry) (Fig. $8 c, d$ ) show the effects of mechanical treatment of the composite, as well as the presence of hydrophobic AM1, which binds a small amount of water according to the IR spectra (Fig. 3). The IUWCSD curves (note that the amounts of water at $h=0.1 \mathrm{~g} / \mathrm{g}$ is much smaller than the pore volume of nanosilicas studied) are located in the range of mesopores $(1 \mathrm{~nm}<R<$ $25 \mathrm{~nm}$, Fig. $8 c, d$, and Table $1, V_{\text {meso }}$ and $S_{\text {meso }}$ ) with a certain trend to fill nanopores at $R<1 \mathrm{~nm}$ (Fig. $8 c$, and Table $1, V_{\text {nano }}$ and $S_{\text {nano). The latter }}$ can be caused by the influence of adsorbed water on the structure of secondary particles formed by NPNP. In other words, water molecules can penetrate between adjacent NPNP in aggregates that results in an increase in contribution of narrow voids at $R<1 \mathrm{~nm}$ in comparison to the dry powders. Water at $h=0.1 \mathrm{~g} / \mathrm{g}$ does not locate in macropores (Table 1), since $V_{\text {macro }}=0$ and $S_{\text {macro }}=0$ for all samples. 


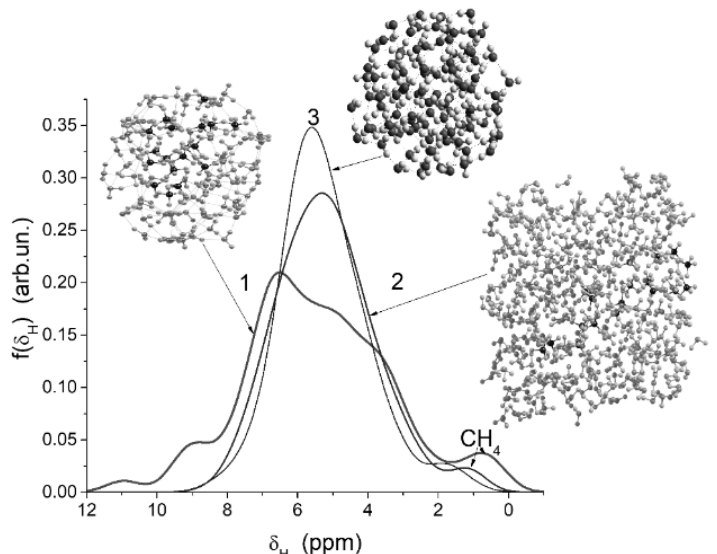

Fig. 13. ${ }^{1} \mathrm{H}$ NMR spectra of water and methane in mixed clusters, in which water molecules form 'nanopores' for methane molecules: (1)

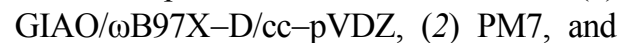
(3) $100 \mathrm{H}_{2} \mathrm{O}(\mathrm{GIAO} / \omega \mathrm{B} 97 \mathrm{X}-\mathrm{D} / \mathrm{cc}-\mathrm{pVDZ})$

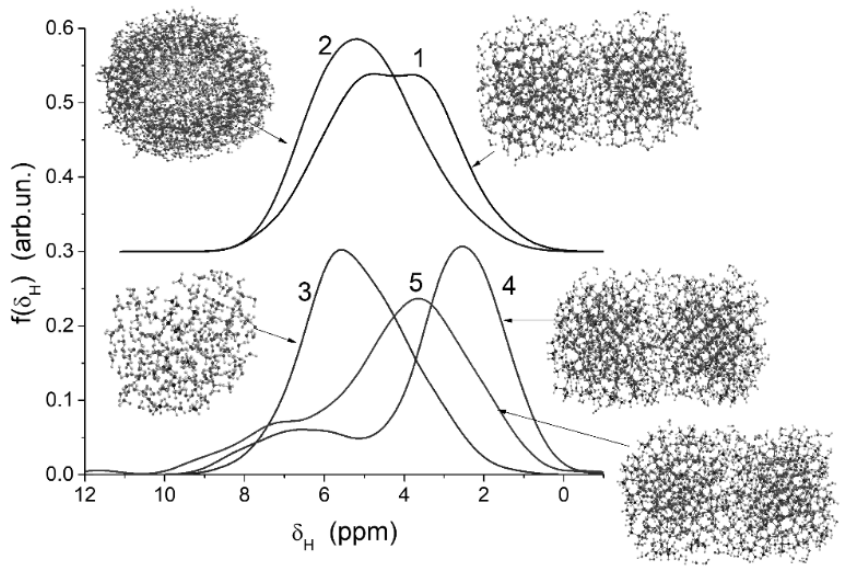

Fig. 14. Theoretical ${ }^{1} \mathrm{H}$ NMR spectra of water bound to two silica NPNP (curve 1), porous silica particle (2), water in a cluster with methane (3), water and TMS groups at a surface of two silica NPNP without methane (4) and with methane (5) $(\operatorname{PM7}(1,2,4,5)$

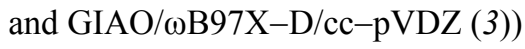

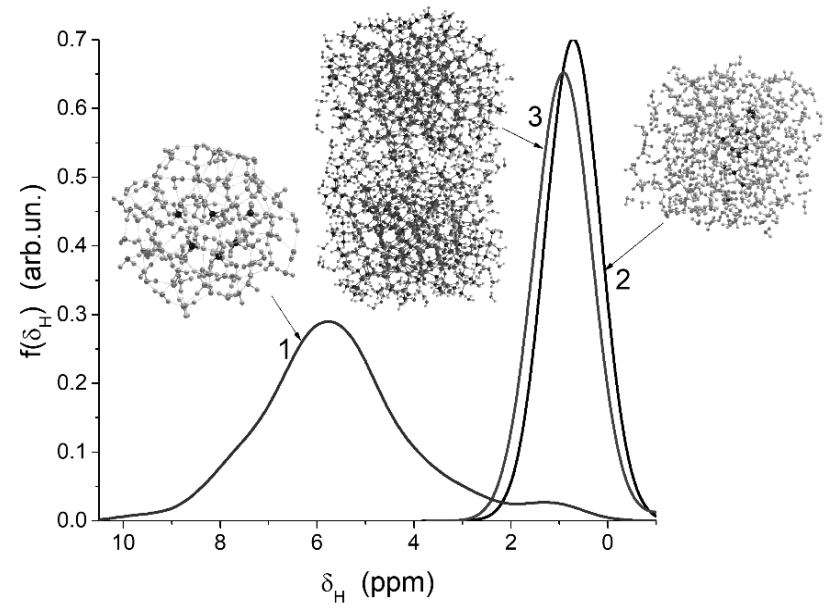

Fig. 15. Theoretical ${ }^{1} \mathrm{H}$ NMR spectra of (1) $100 \mathrm{H}_{2} \mathrm{O} / 6 \mathrm{CH}_{4}(\mathrm{GIAO} / \mathrm{SMG} / \omega B 97 \mathrm{X}-\mathrm{D} / \mathrm{cc}-\mathrm{p} V D Z)$, (2) $321 \mathrm{H}_{2} \mathrm{O} / 18 \mathrm{CH} 4$ (PM7), and (3) water and TMS groups at a surface of two silica NPNP with adsorbed methane (PM7) (curves 2 and 3 show only methane contributions into the ${ }^{1} \mathrm{H}$ NMR spectra); all the spectra are normalized

\section{CONCLUSION}

Organic liquids (acetone and ethanol) with low freezing points can form clusters located in voids between nanoparticles of hydrophilic A-300 and hydrophobic AM1 and characterized by low mobility due to confined space effects. A fraction of immobile molecules does not contribute the ${ }^{1} \mathrm{H}$ NMR spectra of static samples due to their broadened spectral lines and a narrow bandwidth of the NMR spectrometer $(20 \mathrm{kHz})$. The volume of the immobile fractions is larger than the volume of pores of A-300 in the A-300/AM1 (1:5) blend. This suggests that organic molecules can be strongly bound in voids of both AM1 and A-300. Then the volume of immobile liquids corresponds to volume of nano and mesopores of both silicas in the blend.

Methane adsorbed to dense A-300 or differently treated A-300/AM1, which (A-300) are weakly pre-hydrated at $h=0.6 \mathrm{~g} / \mathrm{g}$ for A-300 or $0.1 \mathrm{~g} / \mathrm{g}$ re-calculated for both silicas, is characterized by increased ${ }^{1} \mathrm{H}$ NMR signal intensity with increasing temperature. This effect is due to enhanced mobility of the methane 
molecules with $T$, because at low temperatures these molecules are practically immobile in voids between nanoparticles and frozen or poorly mobile water clusters, which partially fill narrow pores (voids) in NPNP aggregates and agglomerates. Maximal sorption of methane $(25 \mathrm{mg} / \mathrm{g})$ is observed for mechanoactivated A-300/AM1 (1:5) blend at $h=0.1 \mathrm{~g} / \mathrm{g}$. The adsorption of methane is lower onto dense A-300 (bulk density $\rho_{\mathrm{b}}=0.25 \mathrm{~g} / \mathrm{cm}^{3}$ ) and weakly treated dense A-300/AM1 at the same $h$ value $(0.1 \mathrm{~g} / \mathrm{g}): 2.5$ and $10 \mathrm{mg} / \mathrm{g}$, respectively. Thus, appropriate treatment of the blends with hydrophilic and hydrophobic nanosilicas with a small amount of pre-adsorbed water (to control the confined space effects) can lead to a strong increase in the adsorption of methane.

\title{
Міжфазна поведінка метану і органічних розчинників з низькою точкою замерзання при взасмодії з гідрофільним та гідрофобним кремнеземом
}

\author{
В.М. Гунько, В.В. Туров, Т.В. Крупська
}

Інститут хімії поверхні ім. О.О. Чуйка Наиіональної академії наук України вул. Генерала Наумова, 17, Київ, 03164, Україна, vlad_gunko@ukr.net

\begin{abstract}
Характеристики фазового стану адсорбованої речовини при зміні температури часто невідомі через вилив ефектів обмеженого простору в порах адсорбентів на зв'язані з поверхнею сполуки. Теорія адсорбиіі вважає, що на поверхні або в порах адсорбентів адсорбат формує флюїд, густина якого має проміжне значення між густиною газу і рідини. Метою роботи було вивчення можливості переходу адсорбованих речовин у твердий стан при температурі вище точки замерзання. Адсорбиія розчинників (ацетон, етанол) на гідро-ущільненому кремнеземі A-300 та його сумімі з гідрофобним АM1 (A-300, модифікований диметилдихлорсиланом), адсорбиія метану на гідратовані $(h=0.1$ г/2) кремнеземи та поведінка води в залежності від температури були проаналізовані з використанням ЯМР ${ }^{1}$ Н спектроскопії, кріопорометрії $i$ квантової хімії. Частина органічних сполук, адсорбованих на кремнеземі, є нерухомою при температурах вище за їхню точку замерзання, і вони не дають внеску в спектри ЯМР статичних зразків. Сигнал метану зростає з температурою внаслідок підвищення молекулярної рухливості і структурних змін у кластерах рухливої води, які є зв'язаними у порожнинах проміж наночастинками кремнезему, що утворюють агрегати. Більше ущільнення А-300, ніж A-300/AM1 (внаслідок ефекту наночастинок АM1, які перешкоджають формуванню міцних контактів між гідрофільними наночастинками А-300), веде до зменшення адсорбиії метану. Сильніша механічна обробка $A-300 / A M 1$ ( $h=0.1$ г/2) посилюе адсорбиію метану. Цей ефект пов'язаний з підвищенням рухливості молекул метану з $T$, оскільки при низьких температурах иі молекули практично нерухомі в пустотах між наночастинками $i$ замороженими або слабко рухливими кластерами води, які частково заповнюють вузькі пори (порожннини) в агрегатах $i$ агломератах NPNP.
\end{abstract}

Ключові слова: пірогенний кремнезем, гідрофобізований кремнезем, організація зв'язаної води, адсорбиія метану, адсорбиія органічних розчинників, низькотемпературна ЯМР ${ }^{l}$ Н спектроскопія 


\title{
Поведение метана и органических растворителей с низкой точкой замерзания на границах раздела при взаимодействии с гидрофильным и гидрофобным кремнеземом
}

\author{
В.М. Гунько, В.В. Туров, Т.В. Крупская
}

\author{
Институт химии поверхности им. А.А. Чуйко Наииональной академии наук Украины \\ ул. Генерала Наумова, 17, Киев, 03164, Украина, vlad_gunko@ukr.net
}

\begin{abstract}
Характеристики фазового состояния адсорбированного вещества при изменении температуры часто неизвестны из-за влияния эффектов ограниченного пространства в порах адсорбентов на связанные с поверхностью соединения. Теория адсорбиии считает, что на поверхности или в порах адсорбентов адсорбат формирует флюид, плотность которого имеет промежуточное значение между плотностью газа и жидкости. Целью работы было изучение возможности перехода адсорбированных веществ в твердое состояние при температуре выше точки замерзания. Адсорбиия растворителей (ацетон, этанол) на гидро-уплотненном кремнеземе А-300 и его смеси с гидрофобным AM1 (A-300, модифицированный диметилдихлорсиланом), адсорбиия метана на гидратированных $(h=0.1$ г/2) кремнеземах и поведение воды в зависимости от температуры были проанализированы с использованием ЯМР ${ }^{1} H$ спектроскопии, криопорометрии и квантовой химии. Часть органических соединений, адсорбированных на кремнеземе, является неподвижной при температурах выще точки их замерзания, и они не дают вклад в спектры ЯМР статических образиов. Сигнал метана растет с температурой вследствие повышения молекулярной подвижности и структурных изменений в кластерах подвижной воды, которые связаны в пустотах между наночастииами кремнезема, которые образуют агрегаты. Больщее уплотнение A-300, чем A-300/AMI (вследствие эффекта наночастии AM1, которые препятствуют формированию прочных контактов между гидрофильными наночастицами А-300), приводит к уменьшению адсорбиии метана. Более сильная механическая обработка A-300/AM1 (h=0.1 г/2) усиливает адсорбиию метана. Этот эффект связан с повышением подвижности молекул метана с $T$, поскольку при низких температурах эти молекуль практически неподвижны в пустотах между наночастицами и замороженными или слабо подвижными кластерами воды, которые частично заполняют узкие поры (пустоты) в агрегатах и агломератах NPNP.
\end{abstract}

Ключевые слова: пирогенный кремнезем, гидрофобизованный кремнезем, организаиия связанной воды, адсорбиия метана, адсорбиия органических растворителей, низкотемпературная ЯМР ${ }^{l}$ Н спектроскопия

\section{REFERENCES}

1. Adamson A.W., Gast A.P. Physical Chemistry of Surface. 6th Edition. (New York: Wiley, 1997).

2. Gregg S.J., Sing K.S.W. Adsorption, Surface Area and Porosity. (London: Academic Press, 1982).

3. Parfitt G.D., Rochester C.H. Adsorption from Solution at the Solid/Liquid Interface. (London: Academic Press, 1983).

4. Lambert R.M., Pacchioni G. Chemisorption and Reactivity on Supported Clusters and Thin Films. (Kluwer Academic Publishers, 1997).

5. Chattoray D.K., Birdi K.S. Adsorption and the Gibbs Surface Excess. (New York: Plenum Press, 1984).

6. Swenson J., Elamin K., Jansson H., Kittaka S. Why is there no clear glass transition of confined water? Chem. Phys. 2013. 424: 20.

7. Rice S.A. Structure in confined colloid suspensions. Chem. Phys. Lett. 2009. 479(1-3): 1.

8. Mahadevan T., Kojic M., Ferrari M., Ziemys A. Mechanisms of reduced solute diffusivity at nanoconfined solid-liquid interface. Chem. Phys. 2013. 421: 15.

9. Jagadeesh B., Prabhakar A., Demco D.E., Buda A., Blümich B. Surface induced molecular dynamics of thin lipid films confined to submicron cavities: A ${ }^{1} \mathrm{H}$ multiple-quantum NMR study. Chem. Phys. Lett. 2005. 404(1-3): 177.

10. Guégan R., Morineau D., Alba-Simionesco C. Interfacial structure of an H-bonding liquid confined into silica nanopore with surface silanols. Chem. Phys. 2005. 317(2-3): 236.

11. Gordillo M.C., Martí J. Hydrogen bond structure of liquid water confined in nanotubes. Chem. Phys. Lett. 2000. 329(5-6): 341.

12. Dore J. Structural studies of water in confined geometry by neutron diffraction. Chem. Phys. 2000. 258(2-3): 327. 
13. Soper A.K. Radical re-appraisal of water structure in hydrophilic confinement. Chem. Phys. Lett. 2013. 590: 1.

14. Hodgson A., Haq S. Water adsorption and the wetting of metal surfaces. Surf. Sci. Rep. 2009. 64(9): 381.

15. Gun'ko V.M., Turov V.V. Nuclear Magnetic Resonance Studies of Interfacial Phenomena. (Boca Raton: CRC Press, 2013).

16. Legrand A.P. The Surface Properties of Silicas. (New York: Wiley, 1998).

17. Bergna H.E. Colloidal Silica: Fundamentals and Applications. (Salisbury: Taylor \& Francis LLC, 2005).

18. Hubbard A.T. Encyclopedia of Surface and Colloid Science. (New York, Marcel Dekker, 2002).

19. Gilli G., Gilli P. The Nature of the Hydrogen Bond. Outline of a Comprehensive Hydrogen Bond Theory. (Oxford: Oxford University Press, 2009).

20. Chaplin M. Water Structure and Science. http://www.lsbu.ac.uk/water/. 11 July, 2017.

21. Mitchell J., Webber J.B.W., Strange J.H. Nuclear magnetic resonance cryoporometry. Phys. Rep. 2008. $461: 1$.

22. Petrov O.V., Furó I. NMR cryoporometry: Principles, applications and potential. Prog. Nucl. Magn. Reson. Spectrosc. 2009. 54(2): 97.

23. Aksnes D.W., Forl K., Kimtys L. Pore size distribution in mesoporous materials as studied by ${ }^{1} \mathrm{H}$ NMR. Phys. Chem. Chem. Phys. 2001. 3: 3203.

24. Iler R.K. The Chemistry of Silica. (Chichester: Wiley, 1979).

25. Gun'ko V.M., Sheeran D.J., Augustine S.M., Blitz J.P. Structural and energetic characteristics of silicas modified by organosilicon compounds. J. Colloid Interface Sci. 2002. 249(1): 123.

26. Wang L., Yu Q. Methane adsorption on porous nano-silica in the presence of water: An experimental and ab initio study. J. Colloid Interface Sci. 2016. 467: 60.

27. Sizova A.A., Sizov V. V., Brodskaya E.N. Adsorption of $\mathrm{CO}_{2} / \mathrm{CH}_{4}$ and $\mathrm{CO}_{2} / \mathrm{N}_{2}$ mixtures in SBA-15 and CMK5 in the presence of water: A computer simulation study. Colloids Surf. A. 2015. 474: 76.

28. Liu X., Li J., Zhou L. Adsorption of $\mathrm{CO}_{2}, \mathrm{CH}_{4}$ and $\mathrm{N}_{2}$ on ordered mesoporous silica molecular sieve. Chem. Phys. Lett. 2005. 415(4-6): 198.

29. Govindaraj V., Mech D., Pandey G., Nagarajan R., Sangwai J.S. Kinetics of methane hydrate formation in the presence of activated carbon and nano-silica suspensions in pure water. J. Nat. Gas Sci. Eng. 2015. 26: 810.

30. He P., Liu H., Zhu J., Li Y., Huang S., Wang P., Tian H. Tests of excess entropy scaling laws for diffusion of methane in silica nanopores. Chem. Phys. Lett. 2012. 535: 84

31. Takaba H., Yamamoto A., Hayamizu K., Oumi Y. Dependence of the diffusion coefficients of methane in silicalite on diffusion distance as investigated by ${ }^{1} \mathrm{H}$ PFG NMR. Chem. Phys. Lett. 2004. 393(1-3): 87.

32. Lloyd P., Berg O., Thiyagarajan P., Trouw F.R., Chronister E.L. Methane dynamics in porous xerogels characterized by small-angle and quasielastic neutron scattering. Chem. Phys. Lett. 2000. 328(1-2): 203.

33. Brovchenko I., Oleinikova A. Interfacial and Confined Water. (Amsterdam: Elsevier, 2008).

34. Drioli E., Giorno L. Comprehensive Membrane Science and Engineering. (Amsterdam: Elsevier, 2010).

35. Basile A., Figoli A., Khayet M. Pervaporation, Vapour Permeation and Membrane Distillation. Principles and Applications. Woodhead Publishing Series in Energy: N 77. (Amsterdam: Elsevier, 2015).

36. Lipkowski J. Reference Module in Chemistry, Molecular Sciences and Chemical Engineering. Comprehensive Supramolecular Chemistry II. (Amsterdam: Elsevier, 2017) 89.

37. Israelachvili J.N. Intermolecular and Surface Forces. Third Edition. (Amsterdam: Elsevier, 2011).

38. Zolfaghari A., Dehghanpour H., Holyk J. Water sorption behaviour of gas shales: I. Role of clays. Int. J. Coal Geol. 2017. 179: 130.

39. Basic Characteristics of Aerosil. Technical Bulletin Pigments. N 11. Degussa AG, Hanau, 1997.

40. Kulkarni P., Baron P.A., Willeke K. Aerosol Measurement: Principles, Techniques, and Applications. Third Edition. (New York: John Wiley \& Sons, 2011).

41. Büchel K.H., Moretto H.-H., Woditsch P. Industrial Inorganic Chemistry. (Weinheim: Wiley-VCH Verlag $\mathrm{GmbH}, 2000)$.

42. Auner N., Weis J. Organosilicon Chemistry VI. (Weinheim: Wiley-VCH Verlag GmbH, 2005).

43. Piemonte V., De Falco M., Basile A. Sustainable Development in Chemical Engineering - Innovative Technologies. First Edition. (Chichester, UK: John Wiley \& Sons, 2013).

44. Camenzind A., Caseri W.R., Pratsinis S.E. Flame-made nanoparticles for nanocomposites. Nano Today. 2010. 5(1): 48.

45. Gun'ko V.M., Zarko V.I., Chuikov B.A., Dudnik V.V., Ptushinskii Yu.G., Voronin E.F., Pakhlov E.M., Chuiko A.A. Temperature-programmed desorption of water from fumed silica, silica/titania, and silica/alumina. Int. J. Mass Spectrom. Ion Processes. 1998. 172(3): 161

46. Gun'ko V.M., Turov V.V., Bogatyrev V.M., Petin A.Y., Turov A.V., Trachevskyi V.V., Blitz J.P. The influence of pre-adsorbed water on adsorption of methane on fumed and nanoporous silicas. Appl. Surf. Sci. 2011. 258(4): 1306. 
47. Gun'ko V.M., Turov V.V., Turov A.V. Hydrogen peroxide-water mixture bound to nanostructured silica. Chem. Phys. Lett. 2012. 531: 132.

48. Frisch M.J., Trucks G.W., Schlegel H.B., Scuseria G.E., Robb M.A., Cheeseman J.R., Scalmani G., Barone V., Mennucci B., Petersson G.A., Nakatsuji H., Caricato M., Li X., Hratchian H.P., Izmaylov A.F., Bloino J., Zheng G., Sonnenberg J.L., Hada M., Ehara M., Toyota K., Fukuda R., Hasegawa J., Ishida M., Nakajima T., Honda Y., Kitao O., Nakai H., Vreven T., Montgomery, Jr. J.A., Peralta J.E., Ogliaro F., Bearpark M., Heyd J.J., Brothers E., Kudin K.N., Staroverov V.N., Keith T., Kobayashi R., Normand J., Raghavachari K., Rendell A., Burant J.C., Iyengar S.S., Tomasi J., Cossi M., Rega N., Millam J.M., Klene M., Knox J.E., Cross J.B., Bakken V., Adamo C., Jaramillo J., Gomperts R., Stratmann R.E., Yazyev O., Austin A.J., Cammi R., Pomelli C., Ochterski J.W., Martin R.L., Morokuma K., Zakrzewski V.G., Voth G.A., Salvador P., Dannenberg J.J., Dapprich S., Daniels A.D., Farkas O., Foresman J.B., Ortiz J.V., Cioslowski J., Fox D.J., Gaussian 09, Revision D.01, Gaussian, Inc., Wallingford CT, 2013.

49. Chai J.-D., Head-Gordon M. Long-range corrected hybrid density functionals with damped atom-atom dispersion corrections. Phys. Chem. Chem. Phys. 2008. 10(44): 6615.

50. Marenich A.V., Cramer C.J., Truhlar D.G. Universal solvation model based on solute electron density and on a continuum model of the solvent defined by the bulk dielectric constant and atomic surface tensions. J. Phys. Chem. B. 2009. 113(18): 6378.

51. Stewart J.J.P. MOPAC2016, Stewart Computational Chemistry, web: HTTP://OpenMOPAC.net, 2017.

52. Stewart J.J.P. Optimization of parameters for semiempirical methods VI: more modifications to the NDDO approximations and re-optimization of parameters. J. Mol. Mod. 2013. 19(1): 1.

53. Gun'ko V.M., Turov V.V., Zarko V.I., Pakhlov E.M., Matkovsky A.K., Oranska O.I., Palyanytsya B.B., Remez O.S., Nychiporuk Y.M., Ptushinskii Y.G., Leboda R., Skubiszewska-Zięba J. Cryogelation of individual and complex nanooxides under different conditions. Colloids Surf. A. 2014. 456: 261.

54. Gun'ko V.M., Zarko V.I., Pakhlov E.M., Matkovsky A.K., Remez O.S., Charmas B., Skubiszewska-Zięba J. Low-temperature high-pressure cryogelation of nanooxides. J. Sol-Gel Sci. Technol. 2015. 74(1): 45.

55. Gun'ko V.M. Composite materials: textural characteristics. Appl. Surf. Sci. 2014. 307: 444.

56. Gun'ko V.M., Turov V.V., Zarko V.I., Goncharuk O.V., Pahklov E.M., Skubiszewska-Zięba J., Blitz J.P. Interfacial phenomena at a surface of individual and complex fumed nanooxides. Adv. Colloid Interface Sci. 2016. 235: 108 . 